\title{
Physical Activity, Obesity, Family History, and Their Associations with Hypertension among the Elderly in Aceh Singkil, Aceh
}

\author{
Ricca Nophia Amra, Fazidah Aguslina Siregar, Erna Mutiara
}

Masters Program in Public Health, Universitas Sumatera Utara

\section{ABSTRACT}

Background: Hypertension is an important global health challenge due to its high prevalence and resulting cardiovascular disease and chronic kidney disease. This study aimed to examine the associations of physical activity, obesity, family history, with hypertension among the elderly in Aceh Singkil, Aceh.

Subjects and Method: This was a case control study carried out in Aceh Singkil, Aceh, Indonesia. A sample of 132 elderly was selected for this study, consisting 66 elderly with hypertension and 66 elderly without hypertension. The dependent variable was hypertension. The independent variables were physical activity, obesity, and family history. Hypertension data was measured by sphygmomanometer. The other data were collected by questionnaire. The data were analyzed by a multiple logistic regression model.
Results: Hypertension was associated with physical inactivity $(\mathrm{OR}=5.12 ; 95 \% \mathrm{CI}=2.41$ to 10.86 ; $\mathrm{p}<0.001)$, obesity $(\mathrm{OR}=3.30 ; 95 \% \mathrm{CI}=1.61$ to 6.74; $\mathrm{p}<0.001)$, and family history $(\mathrm{OR}=7.73$; $95 \% \mathrm{CI}=3.56$ to $16.78 ; \mathrm{p}<0.001$ ).

Conclusion: Physical activity, obesity, and family history, are associated with an increased risk of hypertension.

Keywords: physical activity, obesity, family history, hypertension

\section{Correspondence:}

Ricca Nophia Amra. Masters Program in Public Health, Universitas Sumatera Utara, Medan, North Sumatera. Email: ricca.ubudiyah@gmail.com. Mobile: 085260686305

\section{Cite this as:}

Amra RN, Siregar FA, Mutiara E (2020). Physical Activity, Obesity, Family History, and Their Associations with Hypertension among the Elderly in Aceh Singkil, Aceh. J Epidemiol Public Healt. 5(1): 45-51. https://doi.org/10.26911/jepublichealth.2020.05.01.05

cc) (i) (-) Journal of Epidemiology and Public Health is licensed under a Creative Commons

\section{BACKGROUND}

Hypertension caused 9.4 million deaths worldwide each year. Data from the Global Status Report on Non-communicable Diseases 2010 from the World Health Organization (WHO) states that $40 \%$ of developing economies countries have hypertension, whereas developed countries are only 35\%. Africa holds the top position of hypertension sufferers by $46 \%$. The American region is in the last position by $35 \%$. In Southeast Asia, 36\% of adults suffer from hypertension and cause the death of nearly 1.5 million people each year (World Health Organization, 2013).

Non-communicable diseases data in Basic Health Research (Riskesdas) in 2013 showed that the prevalence of hypertension in Indonesia was 25.8\%, the highest in Bangka Belitung (30.9\%), South Kalimantan (30.8\%), East Kalimantan (29.6\%) and West Java (29.4\%). An increase in the prevalence of hypertension in Indonesia based on the results of interviews conducted from $7.6 \%$ in 2007 to $9.5 \%$ in 2013 (Health Research and Development Agency, 2013).

Hypertension is called "The Silent Killer" because this disease is a hidden killer and patients usually do not know that they suffer from hypertension before checking blood pressure. In general, hypertension sufferers do not experience symptoms before complications occur (Bustan, 2012). 
Amra et al./ Physical Activity, Obesity, Family History, and Their Associations with Hypertension

In Indonesia, 25.8\% population suffer from hypertension. If the current population of Indonesia is 252,124,458 people, there are $65,048,110$ people suffering from hypertension (Ministry of Health, 2015). The elderly morbidity rate in Indonesia in 2014 was 25.05\%. The provinces with the highest rates of elderly health complaints were West Nusa Tenggara (66.36\%), Aceh (65.98\%), Gorontalo (63.95\%) and South Kalimantan (60.71\%) (Central Statistics Agency, 2010).

Based on the prevalence of hypertension in Aceh in the population aged $\geq 18$ years, it was recorded at $21.5 \%$ and hypertension is in the fourth rank among the many diseases suffered by the people in Aceh. Data on the profile of the Aceh Singkil District Health Office in 2015 showed that hypertension cases in Aceh Singkil District were 953 cases. In 2016, the data showed that the number of hypertension sufferers in the elderly was 1,102 cases, aged 55-59 years old was $34 \%$, aged $60-69$ years was $43 \%$ and aged $>70$ years was $23 \%$. In the working area of Suro Health Center, Suro District, Aceh Singkil District, the number of hypertension sufferers from January-December 2016 was 16\% (Aceh Singkil District Health Office, 2015).

\section{SUBJECTS AND METHOD}

\section{Study Design}

This study was an observational analytic study using case control design. This study aimed to analyze the risk factors for the incidence of hypertension in the elderly (elderly) in the Suro Public Health Center in Suro District, Aceh Singkil District in 2017 by comparing the case group (the elderly with hypertension) with the control group (the elderly who were not hypertensive).

\section{Population dan Sample}

The population of this study were all elderly ( $\geq 60$ years old) patients with hypertension and those who were not hypertensive in the
Suro Community Health Center, Suro District, Aceh Singkil District, amounting to 818 people. The sample size in this study was 66 samples for cases and 66 samples for controls.

\section{Study Variables}

The dependent variable was hypertension. The independent variables were physical activity, obesity, and family history.

\section{Study Variables}

Hypertension is systolic blood pressure $\geq 140 \mathrm{mmHg}$ and or diastolic blood pressure $\geq 90 \mathrm{mmHg}$ which is measured using a sphygmomanometer.

Physical activity is the intensity of daily physical activity that is measured using the Physical Activity Level (PAL) questionnaire. Less if PAL (1.40-1.69) and enough if PAL (1.70-2.40).

Obesity is the result of measurement of Body Mass Index (BMI) based on the BW/$\mathrm{BH}$ of the elderly

Family history is a history of descent that is owned and associated with hypertension, namely mother, father and indirect, namely the biological grandfather and grandmother with measurement results, yes and no.

\section{Study Instruments}

Study instrument for measuring blood pressure was using a sphygmomanometer, physical activity was measured by the International Physical Activity Questionnaire, obesity was measured using scales (Kg), and Meters (cm) to determine the Body Mass Index (BMI).

\section{Data Analysis}

Analysis of the data in this study was using multiple logistic regression tests.

\section{RESULTS}

1. Sample Characteristics

The characteristics of the sample of this study are described in Table 1. 
Amra et al./ Physical Activity, Obesity, Family History, and Their Associations with Hypertension

Table 1. Characteristics of Respondents Based on Education and Employment

\begin{tabular}{lcc}
\hline Sample Characteristics & n & \% \\
\hline Education & 14 & 10.61 \\
No School & 20 & 15.15 \\
Elementary School & 42 & 31.82 \\
Junior High School. & 38 & 28.79 \\
High School & 18 & 13.64 \\
College & & \\
Employment & 11 & 8.33 \\
Retirement of Civil Servant/Military/Police & 44 & 33.33 \\
Housewife & 54 & 40.91 \\
Entrepreneurs & 23 & 17.42 \\
Others & & 52.27 \\
Family History of Hypertension & 69 & 47.73 \\
Yes & 63 & 46.21 \\
No & & 53.79 \\
Obesity & 61 & 56.82 \\
Yes & 71 & 43.18 \\
No & & \\
Physical Activity & 75 & 45.45 \\
Poor & 57 & 54.55 \\
Adequate & & \\
Smoking & 60 & 53.79 \\
Yes & 72 & \\
No & & \\
Fat Consumption & 61 & \\
High & 71 & \\
Adequate & & \\
\hline
\end{tabular}

The education status of the elderly was mostly junior high school graduates (31.82\%) and the lowest was no school (10.61\%). The employment of the elderly was mostly entrepreneurs (40.91\%) and the least were retired civil servants/military/police (8.33\%). A total of $69(52.27 \%)$ of the elderly have a family history of hypertension. Elderly people who have less physical activity were 75 people
(56.82\%). Elderly people who smoke were 6o people (45.45\%). Elderly with high fat consumption was 61 (46.21\%).

2. Simple Logistic Regression Test Results

The relationship of family history, obesity, and physical activity with the incidence of hypertension was analyzed using the simple logistic regression and described in Table 2. 
Amra et al./ Physical Activity, Obesity, Family History, and Their Associations with Hypertension

Table 2. The Relationship of Family History, Obesity, and Physical Activity with the Occurrence of Hypertension Based on Simple Logistic Regression Test

\begin{tabular}{|c|c|c|c|c|c|c|c|}
\hline \multirow[t]{2}{*}{ Variables } & \multicolumn{2}{|c|}{ Hypertension } & \multicolumn{2}{|c|}{$\begin{array}{l}\text { Non- } \\
\text { hypertension }\end{array}$} & \multirow[t]{2}{*}{ OR } & \multirow[t]{2}{*}{$95 \% \mathrm{CI}$} & \multirow[t]{2}{*}{$\mathbf{p}$} \\
\hline & $\mathrm{n}$ & $\%$ & $\mathrm{n}$ & $\%$ & & & \\
\hline Family & & & & & 7.73 & $3.56-16.78$ & $<0.001$ \\
\hline History & 50 & 72.5 & 19 & 27.5 & & & \\
\hline Yes & 16 & 25.4 & 47 & 74.6 & & & \\
\hline No & & & & & & & \\
\hline Obesity & & & & & 3.30 & $1.61-6.74$ & 0.001 \\
\hline Yes & 40 & 65.6 & 21 & 34.4 & & & \\
\hline No & 26 & 36.6 & 45 & 63.4 & & & \\
\hline Physical & & & & & 5.13 & $2.41-10.86$ & $<0.001$ \\
\hline Activity & 50 & $66.7 \%$ & 25 & $33.3 \%$ & & & \\
\hline Poor & 16 & $28.1 \%$ & 41 & $71.9 \%$ & & & \\
\hline Adequate & & & & & & & \\
\hline
\end{tabular}

The statistical test results in Table 2 showed that there was a relationship between family history and the incidence of hypertension $(\mathrm{OR}=7.73 ; 95 \% \mathrm{CI}=3.56$ to $16.78 ; \mathrm{p}<0.001)$, obesity (OR=3.30; $95 \% \mathrm{CI}=1.61$ to $6.74 ; \mathrm{p}=$ 0.001), physical activity $(\mathrm{OR}=5.13 ; 95 \% \mathrm{CI}=$ 2.41 to $10.86 ; \mathrm{p}<0.001)$.
3. Multiple Logistic Regression Test Results

The relationship of family history, obesity and physical activity with the incidence of hypertension was analyzed using the multiple logistic regression test and is described in Table 3 .

Table 3. Results of Multiple Logistic Regression Analysis of the Effects of Family History, Obesity, and Physical Activity with Hypertension

\begin{tabular}{lccc}
\hline \multicolumn{1}{c}{ Variables } & OR & $\mathbf{9 5 \% ~ C I}$ & p \\
\hline Family history & 6.10 & $2.66-13.99$ & $<0.001$ \\
Physical activity & 2.86 & $1.22-6.73$ & 0.016 \\
Obesity & 2.44 & $1.05-5.65$ & 0.038 \\
\hline
\end{tabular}

The results of the multiple logistic regression test indicated that the variables which were the predictor of hypertension were family history $(\mathrm{OR}=6.10 ; 95 \% \mathrm{CI}=2.66$ to $13.99 \mathrm{l}$; $\mathrm{p}<0.001)$, physical activity $(\mathrm{OR}=2.86 ; 95 \%$ $\mathrm{CI}=1.22$ to $6.73 ; \mathrm{p}=0.016)$, and obesity $(\mathrm{OR}=$ $2.44 ; 95 \% \mathrm{CI}=1.05$ to $5.66 ; \mathrm{p}=0.038)$.

\section{DISCUSSION}

1. The relationship of family history of hypertension with the incidence of hypertension

Multiple logistic regression analysis results showed that people who have a family history of hypertension have a 6.10 times greater chance of experiencing hypertension compared to people who do not have a family history of hypertension.

The result of this study was in line with a study done by Osamor and Owumi (2011) in India which showed that there was a significant relationship between family history and the incidence of hypertension. Heredity has a major role in the incidence of hypertension. Families who have hypertension increase the risk by 2-5 times to reduce hypertension to their descendants. If one of someone's parents has hypertension, then throughout life, the child has a $25 \%$ chance of getting hyperten- 
Amra et al./ Physical Activity, Obesity, Family History, and Their Associations with Hypertension

sion. If the parents have hypertension, then the possibility to get hypertension would be $60 \%$.

Study by Vasantha and Kanniammal (2016) supported that people with a family history of hypertension were 2.61 times more likely to experience hypertension compared to people who do not have a family history of hypertension. ( $\mathrm{OR}=2.61 ; \mathrm{p}=0.002)$.

\section{The relationship of obesity with the incidence of hypertension}

The analysis showed that people who were obese have a 2.44 times greater risk of experiencing hypertension compared with those who were not obese.

The result of this study was in line with the study done by Akintunde et al. (2010) which showed the same result where of 816 respondents who experienced essential hypertension, more than half (494 people) were obese where the results of the independent sample T-test analysis showed a relationship between the average BMI with hypertension. Therefore, it can be concluded that obesity is proven to be a risk factor for hypertension.

The results of this study were also in line with Yusrizal et al. (2016) which stated that there was a positive relationship between BMI and the risk of hypertension. The higher a person's BMI, the greater the chance for hypertension.

Vasantha and Kanniammal (2016) stated that obesity has an effect on the incidence of hypertension. People who have obesity were 1.83 times more likely to have hypertension compared to people who were not obese $(\mathrm{OR}=1.83 ; \mathrm{p}=0.040)$.

Obesity was a major risk for essential hypertension, diabetes and other morbidity that contribute to the development of kidney disease because it mainly increased tubular reabsorption to interfere with the pressure of natriuretic (Jiang et al., 2016).

\section{The relationship of physical activity with the incidence of hypertension}

The analysis shows that people who have less physical activity were 2.86 times more likely to have hypertension compared to people who have enough activity.

The results of this study were in line with study done by Anggara and Prayitno (2013) which showed a significant relationship between physical activity and hypertension with a $\mathrm{p}$ value of $<0.001$.

Study by Abdul-Razak (2016) in Malaysia indicated that the greatest prevalence of hypertension was people in the city due to lack of physical activity and consumption of unhealthy food.

Regular physical activity was beneficial to regulate body weight and strengthen the heart and blood vessels and prevent various diseases, especially hypertension. Then the elderly were expected to exercise regularly at least 30 minutes a day (Yogiantoro, 2009).

Regular physical activity would increase the efforts to maintain body weight and prevent an increase in excess blood pressure over time. A meta-analysis study from Kelley et al. (2003) concluded that physical activity leads to a small but not statistically significant decrease in blood pressure.

Physical inactivity is very positively related to hypertension, and many studies have shown that increased physical activity is effective in the treatment of high blood pressure in various populations (Stamler et al., 1993).

AUTHORS' CONTRIBUTION

Ricca Nophia Amra designed, performed the experiments, and analysed the data. Ricca Nophia Amra wrote the manuscript in consultation with Fazidah Aguslina Siregar and Erna Mutiara.

\section{CONFLICT OF INTEREST}

There was no conflict of interest in this study.

FUNDING AND SPONSORSHIP

This was a self-funded study. 
Amra et al./ Physical Activity, Obesity, Family History, and Their Associations with Hypertension

\section{ACKNOWLEDGEIMENT}

We would like to thank the staff of the Suro Community Health Center in Aceh Singkil, Indonesia for allowing the authors to visit their offices for our study.

\section{REFERENCES}

Abdul-Razak S, Daher AM, Ramli AS, Ariffin F, Mazapuspavina MY, Ambigga KS, et al. (2016). Prevalence, awareness, treatment, control and socio demographic determinants of hypertension in Malaysian adults. BMC Public Health. https://doi.org/10.1186/S12889-016-3008-Y PMID: 27097542

Akintunde AA, Akinwusi PO, Adebayo RA, Ogunyemi S, Opadijo OG (2010). Burden of obesity in essential hypertension: Pattern and prevalence. Niger J Clin Pract. 13(4):399-402. Retrieved from https://www.ncbi.nlm.nih.gov/pubmed/21220853

Anggara FHD, Prayitno N (2013). Faktorfaktor yang berhubungan dengan tekanan darah di Puskesmas Telaga Murni Cikarang Barat Tahun 2012 (Factors Related to Blood Pressure at the West Cikarang Telaga Murni Health Center in 2012). Jurnal Ilmiah Kesehatan. https://doi.org/10.1002/9781444324808.ch3 6

Badan Penelitian dan Pengembangan Kesehatan (2013). Riset Kesehatan Dasar (RISKESDAS) 2013 (Basic Health Research 2013). Laporan Nasional 2013. Retrieved from http://www.depkes.go.id/resources/download/general/Hasil\%20Riskesdas\%202013.pdf

Badan Pusat Statistik (2010). Penduduk lanjut usia (Elderly population). Susenas. Retrieved from https://www.bps.go.id/publication/2010/11/25/o3cc9539a716e 6fc95b49437/statistik-penduduk-lanjut-usia-2009.html
Bustan (2012). Pengantar Epidemiologi (Introduction to Epidemiology). Jakarta: Rineka Cipta.

Jiang SZ, Lu W, Zong XF, Ruan HY, Liu Y (2016). Obesity and hypertension. Exp Ther Med. 12(4): 2395-2399. https://dx.doi.org/10.3892\%2Fetm.2016.3667.

Kelley GA, Kelley KS, Tran ZV (2003). The effects of exercise on resting blood pressure in children and adolescents: A meta-analysis of randomized controlled trials. Preventive Cardiology, 6(1): 8-16. https://doi.org/10.1111/j.1520037X.2003.01224.X

Ministry of Health (2015). Hipertensi (Hypertension). The Silent Killer. Pusdatin. Retrieved from https://pusdatin.kemkes.go.id/article/view/15080300001/hipertensi-the-silent-killer.html

Osamor PE, Owumi BE (2011). Factors associated with treatment compliance in hypertension in southwest Nigeria. $\mathrm{J}$ Health Popul Nutr. 29(6): 619-628. https://doi.org/10.3329/jhpn.v29i6.98 99

Stamler J, Stamler R, Neaton JD (1993). Blood pressure, systolic and diastolic, and cardiovascular risks: US population data. Archives of Internal Medicine. 153(5): 598-615. http://dx.doi.org/10.1001/archinte.1993.004100500 36006

Vasantha P, Kanniammal C (2016). Identification of Risk Factors for Hypertension and Its Complications Among Hypertensive Adults Attending Medical OPDA Hospital Based Case Control Study. International Journal of Pharmaceutical and Clinical Research, 8(8):12151217. https://doi.org/10.4061/2011/563657

WHO (2013). A global brief on Hypertension - World Health Day 2013. In World Health Organization. Retrieved from https://www.who.int/cardiovascular_d 
Amra et al./ Physical Activity, Obesity, Family History, and Their Associations with Hypertension

iseases/publications/global_brief_hype rtension/en/.

Yogiantoro M. (2009). Hipertensi Esensial. Buku ajar ilmu penyakit dalam jilid II (Essential Hypertension. Medical science books in volume II). Edisi kelima. Jakarta: Interna Publishing, 1079-82.
Yusrizal M, Indarto D, Akhyar M (2016). Risk of Hypertension in Adolescents with Over Nutritional Status in Pangkalpinang, Indonesia. J Epidemiol Public Health 1(1): 27-36. https://doi.org/10.26911/jepublichealth.2016.01.0 1.04 